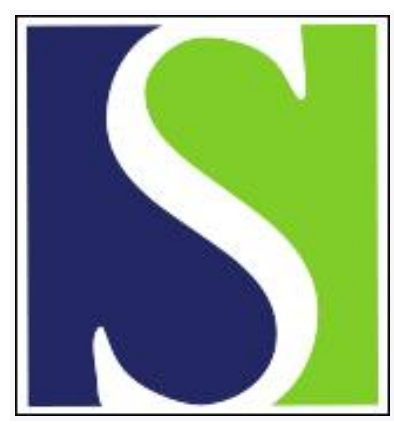

Scand J Work Environ Health 1986;12(5):512

https://doi.org/10.5271/sjweh.2116

Issue date: Oct 1986

Harmful health effects of exposure to kerosene and antirust

oil.

by Jarvholm B, Lavenius B, Bjorn A

Refers to the following text of the Journal: 1981;7(3):179-184

This article in PubMed: www.ncbi.nlm.nih.gov/pubmed/2947321 


\section{Harmful health effects of exposure to kerosene and antirust oil}

The paper by Jee et al "Prevalence of probable kerosene dermatoses among ball-bearing factory workers" that appeared in volume 12 (1986), number 1 (pages 61-65) of the Scandinavian Journal of Work, Environment \& Health is very interesting. We have had some similar experience in a Swedish ball-bearing factory although the production process in this workplace is probably much more automated, meaning far less skin contact with solvents such as kerosene. However, cotton waste with kerosene is used for degreasing in some places. In 1979 nurses interviewed 148 persons exposed to kerosene and 71 persons with no occupational exposure to skin irritants (1). The results clearly indicated an exposure-dependent effect of kerosene (table 1). Most cases experienced redness and dryness of the skin.

There were different types of kerosene containing from less than $1 \%$ to about $18 \%$ aromatic hydrocarbons. Therefore skin exposure to kerosene can certainly be harmful even if the exposure is far lower than what it probably was in the factory in Taiwan.

The workers in Taiwan also had contact with antirust oils. These oils may contain corrosion inhibitors which may be skin sensitizers, eg, N-phenyl-1naphthylamine. In the mid-1950s the Swedish factory used an antirust oil with about $2 \% \mathrm{~N}$-phenyl-1naphthylamine and an epidemic of eczema occurred among the workers. Later on we found an association between this exposure and cancer (2).
Tabie 1. Dermatitis in persons exposed to kerosene.

\begin{tabular}{lcc}
\hline $\begin{array}{l}\text { Exposure } \\
\text { time } \\
\text { (h/d) }\end{array}$ & $\begin{array}{c}\text { Number } \\
\text { of persons } \\
\text { in study }\end{array}$ & $\begin{array}{c}\text { Percentage of } \\
\text { persons with } \\
\text { dermatitis }\end{array}$ \\
\hline 0 (referents) & 71 & 4 \\
$<1$ & 22 & 5 \\
$1-4$ & 41 & 7 \\
$>4$ & 85 & 14 \\
\hline
\end{tabular}

\section{References}

1. Björn A, Järvholm B, Lavenius B. Narig och torr hy samt luftvägssymtom bland arbetare exponerade för lacknafta. Läkartidningen 80 (1983) 1676-1678.

2. Järvholm B, Lavenius B. A cohort study on cancer among workers exposed to an antirust oil. Scand J Work Environ Health 7 (1981) 179-184.

Bengt Järvholm, MD, ${ }^{1}$ Bengt Lavenius, $\mathrm{MD},{ }^{2}$ Annika Björn $^{2}$

1 Department of Occupational Medicine, Sahlgren Hospital, St Sigfridsg 85, S-412 66 Göteborg, Sweden.

${ }^{2}$ Health Department, AB SKF, S-415 50 Göteborg, Sweden. 